\title{
Floristic diversity of the soil weed seedbank in boro rice fields: in situ and $e x$
} situ evaluation

\author{
$\bowtie$ Fahmida Akter, Mahfuza Begum and Md. Abdus Salam
}

Department of Agronomy, Bangladesh Agricultural University, Mymensingh-2202, Bangladesh

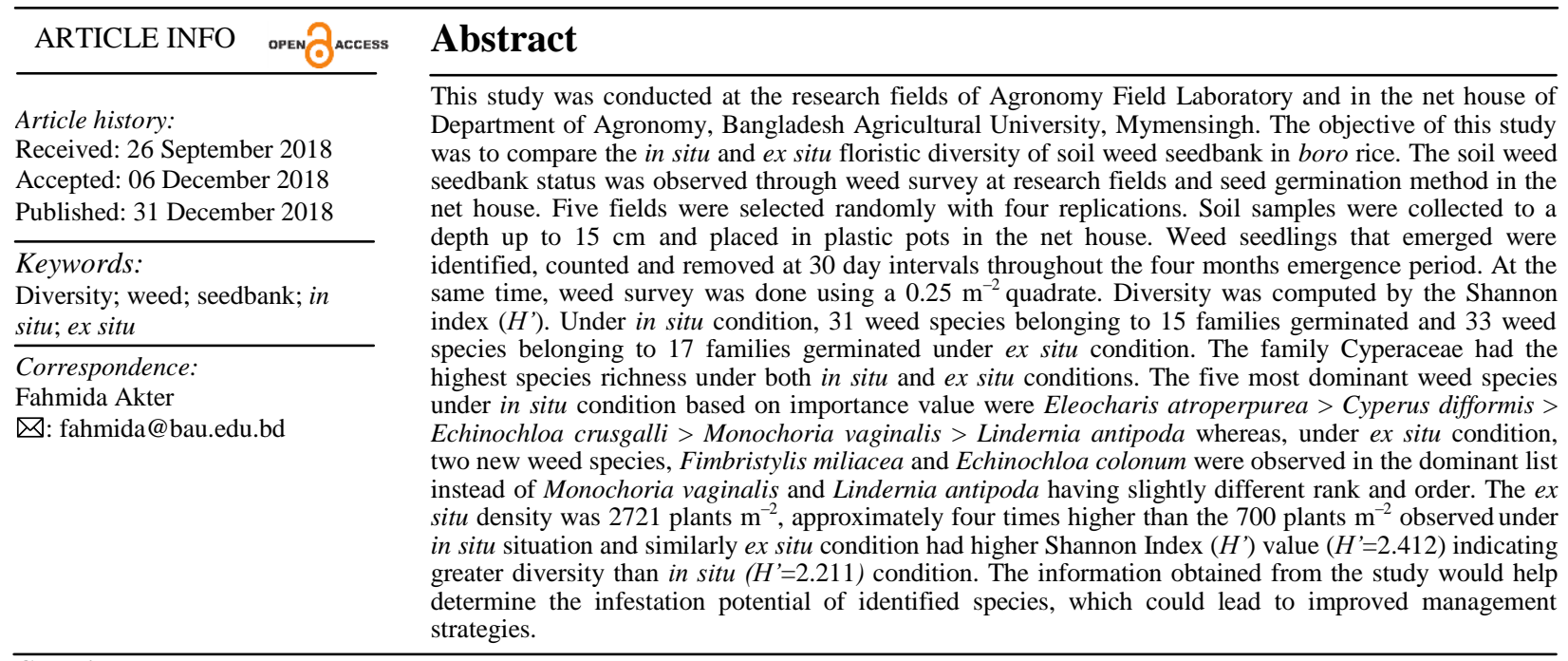

\section{Introduction}

Rice is the world's single most important crop and a primary food source for half of the world's population. The people in Bangladesh depend on rice as staple food and the crop has tremendous influence on agrarian economy of Bangladesh. Food production in Bangladesh is dominated by a single crop (rice) and a single season (boro, which accounts for over $60 \%$ of total rice production) (MoFDM, 2012). Boro rice covers about $11,793,512$ acres area and contributes to $18,937,581 \mathrm{M}$ tons of rice production in the country (BBS, 2016). The average yield of boro rice is low compared to other rice growing countries. BRRI (2008) reported that 70-80\% yield reduction in aus rice, $30-40 \%$ in transplanted aman rice and $22-36 \%$ in boro rice were caused by weed infestation. Chauhan and Johnson (2011) reported as high as 95\% yield reduction in rice due to weed competition throughout the rice growing season. This loss is, therefore, a serious threat for the food deficit countries like Bangladesh. One of the most important, yet often neglected, weed management strategies is to reduce the number of weed seeds present in the field, and thereby limit potential weed populations during crop production. This could be accomplished by managing the weed seedbank.
Weeds are unique group of plant species having the ability to infest and thrive in intensively disturbed habitats, despite extensive efforts to eliminate them. Weeds are successful because of their nature of plasticity that adapt to and survive changes in the environment. At maturity, weeds shed their seeds on agricultural land and thus add to the population of weed seeds in or on the soil which constitutes the weed seedbank. Weed seedbank is the reservoir of viable weed seeds, present on the soil surface and scattered throughout the soil profile (Singh et al., 2012). It consists of both new weed seeds recently shed, and older seeds that have persisted in the soil from previous years. The weed seedbank largely determines the potential density and species composition of weeds that subsequently interfere with crops during the growing season (Forcella, 1993). In this respect, an estimation of the weed seedbank population in the soil, combined with knowledge of the germination and behavior of specific weed species, presents practical opportunities to develop integrated and environmentally sound weed management programs. If prediction of potential weed populations could be done before crops were sown, the infestation of weeds might be reduced by altering crop selection in relation to various patterns of resource competition, soil distribution, plant architectures or changing sowing times to avoid major weed problems. 
In situ study of weed seedbank is the identification and enumeration of weed seedling emergence in the field which might provide a general indication of the composition of the weed flora in the seedbank. On the other hand, weed seedbank study ex situ, that is, the identification and enumeration of weed seedling emergence from soil samples placed in trays in the net house and irrigated daily for longer periods, is more efficient for assessing germination dynamics. Moreover, it is also possible to assess the potential size of the weed seedbank because many species are capable of extended fluxes of emergence over several weeks under favorable environmental conditions. Species those present both in situ and ex situ, demonstrated great plasticity (the capacity to adapt to different sites), as well as tolerance to human activities and stress conditions imposed by environmental factors. As weed seedbank is an indicative of a field's cropping systems history, it would be useful to know if weed seedbank and the aboveground community are closely related. If this relationship were predictive, seedbank data could be used in the design of predictive weed management.

Although a number of studies have evaluated the relationship between the weed seedbank and the floristic compositions, results have not been consistent. While some studies have reported strong relationships between the weed seedbank and aboveground communities (Tuesca et al. 2004; Ndarubu and Fadayomi, 2006), others have found that correlations were generally low and very variable (Cardina and Sparrow, 1996; Webster et al. 2003). In Bangladesh, since almost no study has been done in this context, very little is known about the soil weed seedbank and their pattern of occurrence in crop fields. Therefore, the present study was carried out to assess the total number of weed seeds reserve, species composition and dominant weed species present as well as to compare the floristic diversity, in situ and ex situ of the soil weed seedbank in boro rice field.

\section{Materials and Methods}

This study was carried out at two locations of Bangladesh Agricultural University in Mymensingh district during the period from January to May 2016. In situ study was conducted at the Agronomy Field Laboratory whereas ex situ study was performed in the net house of the same Department. The area was situated under the latitude of $24.75^{\circ} \mathrm{N}$ and the longitude of $90.50^{\circ} \mathrm{E}$ with an elevation of $18 \mathrm{~m}$ above sea level which belongs to the Agroecological region of the Old Brahmaputra Floodplain (AEZ-9). The experimental area is under the sub-tropical climate which is characterized by high temperature, high humidity and heavy precipitation during the months from April to September (Kharif season) and scanty precipitation associated with moderately low temperature during the period from October to March (Rabi season). The soil belonged to the Sonatala series of dark grey floodplain soil type having $\mathrm{pH}$ 6.5. Five boro rice fields were selected from Agronomy Field
Laboratory. Each field was divided into four plots. Each plot was considered as a replication. The size of each plot was $1 \mathrm{~m}^{2}$.

In situ evaluation of seedbank was done by conducting weed survey in half of the area $\left(0.5 \mathrm{~m}^{2}\right)$ of each plot of Agronomy Field Laboratory. A $0.25 \mathrm{~m}^{2}$ quadrate was used to collect data on species composition within 30 days intervals up to harvesting of boro rice. All collected data were converted to per meter square.

For ex situ evaluation, soil samples were collected before transplanting of boro rice. A soil auger was used to take soil samples to a depth up to $15 \mathrm{~cm}$ following a $\mathrm{W}$ shape pattern from in the rest of $0.5 \mathrm{~m}^{2}$ area of the same plots. Each soil sample was weighed approximately $1.5 \mathrm{~kg}$. Samples were bagged and excess air was removed from the bagged sample to reduce the risk of seed germination during storage. Samples of each plot were placed in an individual plastic pot $(28 \mathrm{~cm}$ diameter $\times 10 \mathrm{~cm}$ depth) in the Net house. The soils were daily sprinkled with water as needed in order to keep them moist. Weed seedlings that emerged were identified, counted, and removed at 30 days intervals throughout the four months emergence period. The seedling key of Chancellor (1966) was used to identify weed seedlings. Seedlings that could not be identified down to the species level were transplanted to plastic pots and cultivated until reaching the flowering stage. After the removal of each batch of seedlings, soils were thoroughly mixed in order to expose the weed seeds to the upper level of the soil, and re-wetted to permit further emergence. This process was repeated four times. Seedling emergence counts were converted to number per $\mathrm{m}^{2}$.

The dominant weed species was determined by the calculation of Importance Value (I.V.) which was expressed as:

$$
\text { I.V. }(\%)=\frac{\text { Number of each species in a community }}{\text { Total number of all species in a community }} \times 100
$$

Floristic diversity was assessed by the Shannon index $\left(H^{\prime}\right)$ based on natural logarithm which considers equal weight among rare and abundant species. Higher values of $H^{\prime}$ indicate greater floristic diversity (Shannon and Weaver, 1949).

The Shannon index was computed by the following formula:

$H^{\prime}=\sum-p i \ln p i$

Where,

$\ln$ is the natural logarithm

$p i=n i / N$,

$n i$ is the number of sampled individuals of species $i$

$N$ is the total number of sampled individuals. 


\section{Results}

Composition of weed species under in situ condition Agronomy Field Laboratory, where in situ evaluation has been done, were occupied with 31 weed species belonging to 15 families and 24 genera representing diversity in their composition (Table 1). Eight weed species were found from Poaceae family, five weed species from Cyperaceae family, three from Amaranthaceae family, two weed species from each of the family Commelinaceae, Pontederiaceae and Polygonaceae and one weed species from each of the family from Araceae, Azollaceae, Compositae, Hydrophyllaceae, Marsileaceae, Nymphaeceae, Onagraceae, Rubiaceae and Scrophulariaceae. In case of density, species of the family Cyperaceae largely dominated the soil weed seedbank followed by Poaceae (15.3\%) (Fig. 1). It was observed that, 55.2\% of species present in the seedbank belonged to Cyperaceae family. Among 31 weed species, 18 from broadleaf, eight from grasses and five from sedges were identified (Table 1) which indicated that broadleaves were dominated over grasses and sedges. The five most dominant weed species based on importance value in descending order were Eleocharis atroperpurea (27.3\%) > Cyperus difformis (25.4\%) > Echinochloa crusgalli (12.6\%) > Monochoria vaginalis $(10.4 \%)>$ Lindernia antipoda $(3.9 \%)$ and rest of the species represented $20.4 \%$ (Fig. 2).
Composition of weed species under ex situ condition

Under ex situ condition which was conducted in the net house, a total of 33 weed species were emerged which belonged to 17 families and 27 genera from the weed seedbank (Table 1). Seven weed species from Poaceae family, five weed species from Cyperaceae, three weed species from the family Amaranthaceae, two weed species from each of the family Compositae, Commelinaceae, Scrophulariaceae and Polygonaceae, one weed species from each of the family Azollaceae, Araceae, Chenopodiaceae, Labiatae, Marsileaceae, Onagraceae, Portulaceae, Pontederiaceae, Rubiaceae and Solanaceae. The family with the highest species richness was Cyperaceae which accounted for $53.0 \%$ of the species followed by Poaceae (23.2\%) identified under ex situ condition (Fig. 3). Among the 33 weed species, 21 from broadleaves, seven from grasses and five from sedges were identified (Table 1). So from the experimental result it was found that broadleaves were outnumbered grasses and sedges. According to the importance value of the identified weed species, the descending order of the five most dominant weed species under ex situ condition were Cyperus difformis $(23.6 \%)>$ Eleocharis atroperpurea (16.3\%) > Echinochloa crusgalli $(15.5 \%)>$ Fimbristylis miliacea $(10.2 \%)>$ Echinochloa colonum $(6.2 \%)$ and rest of the weed species represented $28.2 \%$ (Fig. 4).

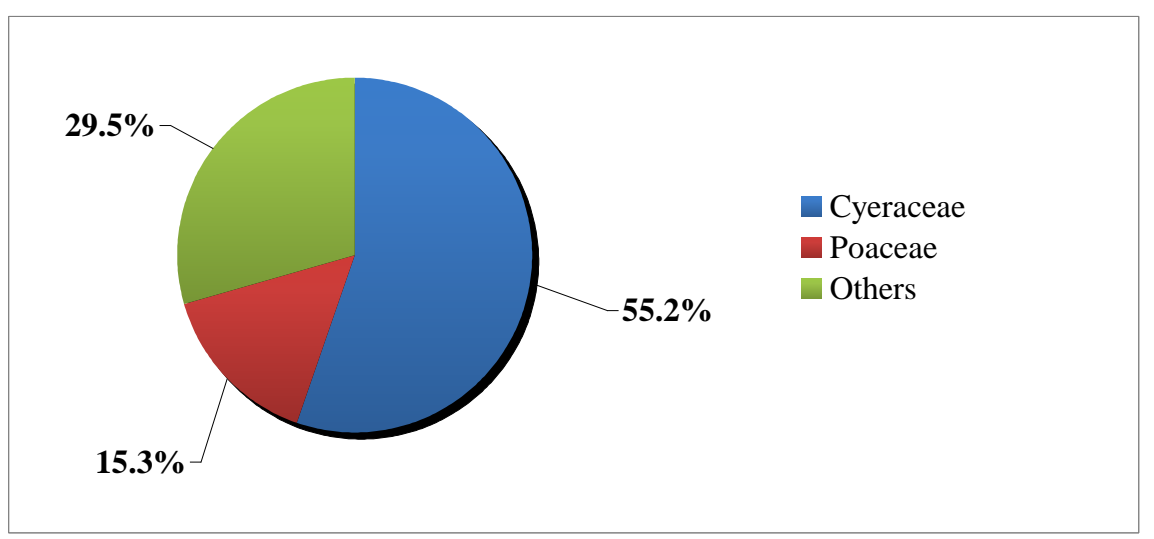

Fig. 1. Two most dominant families in the soil weed seedbank under in situ condition

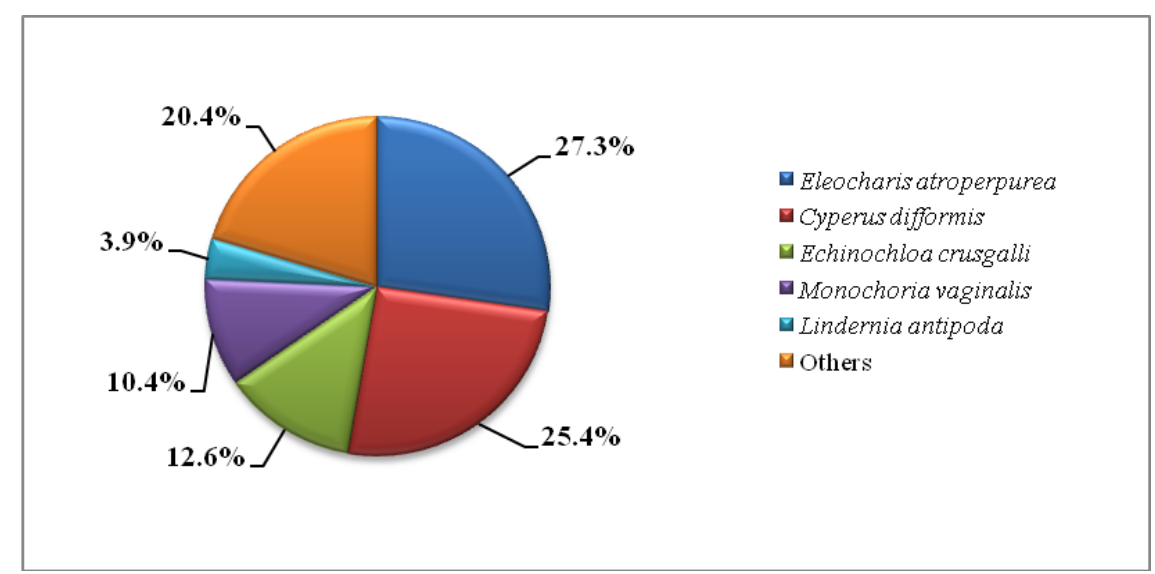

Fig. 2. Five most dominant weed species in the soil weed seedbank under in situ condition based on importance value 


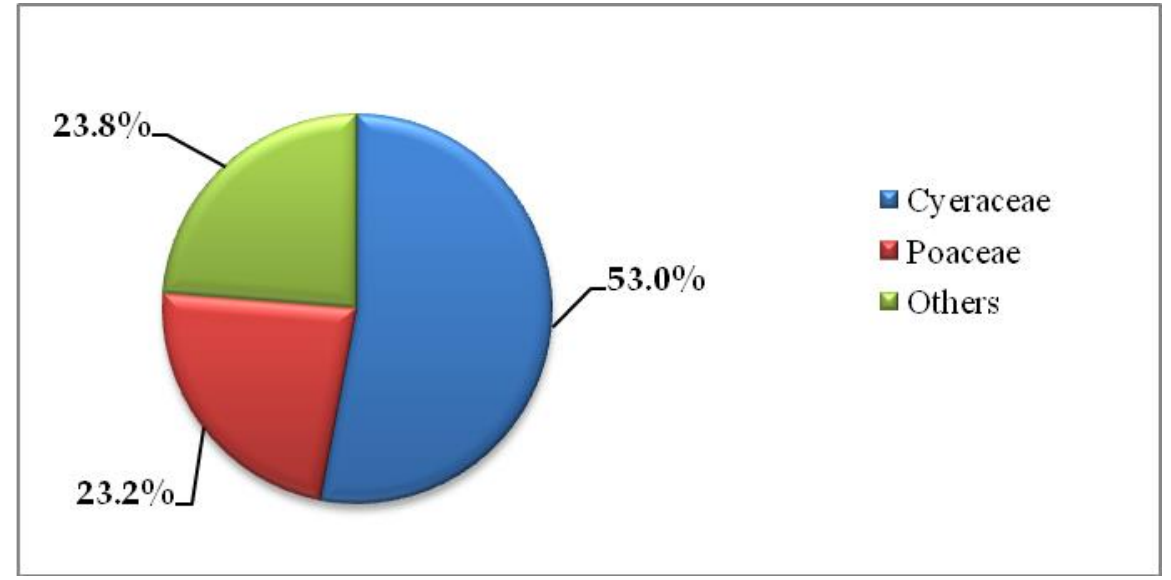

Fig. 3. Two most dominant families in the soil weed seedbank under ex situ condition

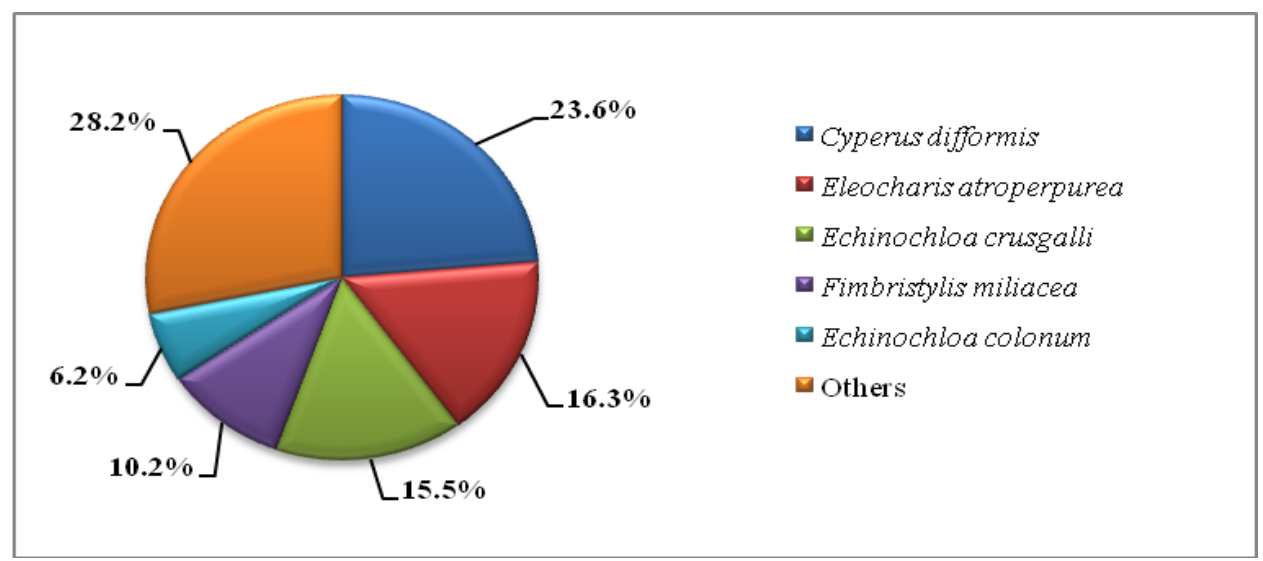

Fig. 4. Five most dominant weed species in the soil weed seedbank under ex situ condition based on importance value

Comparison of soil weed seedbank between in situ and $e x$ situ condition

The higher floristic diversity, with the highest number of families, genera and species, was observed under ex situ condition than in situ condition. A total of 68,408 weed individuals per twenty square meters belonging to 19 families, 32 genera and 39 species were recorded under both in situ and ex situ condition per (Table 1). Of those, 13,996 individuals within 31 species were recorded under in situ and 54,412 individuals within 33 species were recorded under ex situ condition. Among the 19 families, weed species of in situ condition belonged to 15 families and 24 genera and weed species of ex situ condition belonged to 17 families and 27 genera (Fig. 5). Thirteen families were common in both in situ and ex situ condition. Two families such as Hydrophyllaceae and Nymphaceae were only observed under in situ condition and four families such as Chenopodiaceae, Labiatae, Portulaceae and Solanaceae were only present under ex situ condition. The family with the highest species richness based on importance value was Cyperaceae in both conditions. Nine weed species were present under ex situ condition but absent under in situ condition such as Eleusine indica, Cynodon dactylon, Mazus rugosus, Gnaphalium affine, Commelina benghalensis, Portulaca oleracea, Chenopodium album, Solanum rostratum and Leucas aspera. Six weed species were absent under ex situ condition but present under in situ condition such as Digitaria ischaemum, Panicum distichum, Parapholis incurve, Eichhornia crassipes, Nymphaea nouchali and Hydrolea zeylanica. In case of weed density, similar results were obtained that is, the $e x$ situ density was 2721 plants $\mathrm{m}^{-2}$, four times higher than the 700 plants $\mathrm{m}^{-2}$ observed under in situ situation (Fig. 6).

The Shannon diversity index $\left(H^{\prime}\right)$ is an index that is commonly used to characterize species diversity in a community. In the present study, the highest floristic diversity with the highest number of families, genera and species, was observed under ex situ condition than in situ condition in Agronomy fields. Shannon Index $\left(H^{\prime}\right)$ was higher under $e x$ situ condition $\left(H^{\prime}=2.412\right)$ than in situ $\left(H^{\prime}=2.211\right)$ condition. The highest number of individuals and species found under ex situ condition contributed to the great floristic diversity.

The highest percentage of the emerged seedlings was recorded in February under both in situ and ex situ condition (Fig. 7). Weed seedlings continued to emerge up to May but in reduced numbers compared to first flush in the two locations under in situ and ex situ condition. Over the four months emergence period, percent emergence of weed seedlings showed a clear peak and continued to emerge irrespective of the time of all study period, but in reduced numbers under both condition. 
Table 1. Total number of weed seedlings per twenty square meters recorded under in situ and ex situ conditions in the soil weed seedbank of boro rice

\begin{tabular}{|c|c|c|c|c|c|}
\hline $\begin{array}{c}\begin{array}{c}\text { Morphological } \\
\text { type }\end{array} \\
\end{array}$ & Local name & Scientific name & Family & In situ & Ex situ \\
\hline \multirow{12}{*}{ Grasses } & Shama & Echinochloa crusgalli $\mathrm{L}$. & Poaceae & 1768 & 8454 \\
\hline & Chapra & Eleusine indica $\mathrm{L}$. & Poaceae & - & 570 \\
\hline & Khude shama & Echinochloa colonum $\mathrm{L}$. & Poaceae & 32 & 3358 \\
\hline & Arail & Leersia hexandra $\mathrm{L}$. & Poaceae & 118 & 112 \\
\hline & Khudey anguli ghash & Digitaria ischaemum L. & Poaceae & 6 & - \\
\hline & Anguli ghash & Digitaria sanguinalis $\mathrm{L}$. & Poaceae & 98 & 84 \\
\hline & Angta & Panicum distichum $\mathrm{L}$. & Poaceae & 98 & - \\
\hline & Gaicha & Paspalum commersonii Lamk. & Poaceae & 8 & 14 \\
\hline & Chela ghash & Parapholis incurve L. & Poaceae & 14 & - \\
\hline & Durba & Cynodon dactylon $\mathrm{L}$. & Poaceae & - & 42 \\
\hline & Sabuj nakful & Cyperus difformis $\mathrm{L}$. & Cyperaceae & 3556 & 12862 \\
\hline & Panichase & Eleocharis atroperpurea (Retz.) Kunth & Cyperaceae & 3822 & 8860 \\
\hline \multirow[t]{15}{*}{ Sedges } & Joina & Fimbristylis miliacea $\mathrm{L}$. & Cyperaceae & 296 & 5540 \\
\hline & Bara chucha & Cyperus iria $\mathrm{L}$. & Cyperaceae & 48 & 1572 \\
\hline & Khudey patai & Cyperus flavidus $\mathrm{L}$. & Cyperaceae & 4 & 14 \\
\hline & Malancha & Alternanthera philoxeroides $\mathrm{L}$. & Amaranthaceae & 108 & 312 \\
\hline & Chanchi & Alternanthera sessilis $\mathrm{L}$. & Amaranthaceae & 48 & 128 \\
\hline & Shaknotey & Amaranthus viridis L. & Amaranthaceae & 106 & 1458 \\
\hline & Topa pana & Pistia stratiotes L. & Araceae & 170 & 28 \\
\hline & Azolla & Azolla pinnata $\mathrm{L}$. & Azollaceae & 346 & 680 \\
\hline & Bathua & Chenopodium album $\mathrm{L}$. & Chenopodiaceae & - & 14 \\
\hline & Monayna & Commelina diffusa $\mathrm{L}$. & Commelinaceae & 6 & 28 \\
\hline & Kanaibashi & Commelina benghalensis $\mathrm{L}$. & Commelinaceae & - & 14 \\
\hline & Keshuti & Eclipta alba $\mathrm{L}$. & Compositae & 220 & 1758 \\
\hline & Shetlomi & Gnaphalium affine $\mathrm{L}$. & Compositae & - & 56 \\
\hline & Nodulgia & Hydrolea zeylanica $\mathrm{L}$. & Hydrophyllaceae & 26 & - \\
\hline & Shetodrone & Leucas aspera L. & Labiatae & - & 14 \\
\hline \multirow{13}{*}{ Broadleaf weeds } & Sushni shak & Marsilea crenata Presl. & Marsileaceae & 462 & 112 \\
\hline & Panishapla & Nymphaea nouchali Burm. f.' & Nymphaeaceae & 6 & - \\
\hline & Panilong & Ludwigia hyssopifolia (Jacq.) P. H. Raven & Onagraceae & 110 & 772 \\
\hline & Biskatali & Polygonum hydropiper $\mathrm{L}$. & Polygonaceae & 156 & 1670 \\
\hline & Pani morich & Polygonum orientale L. & Polygonaceae & 228 & 1042 \\
\hline & Panikachu & Monochoria vaginalis (Burm. F.) C. Presl. & Pontederiaceae & 1450 & 2914 \\
\hline & Kachuripana & Eichhornia crassipes (Mart.) Solms. & Pontederiaceae & 20 & - \\
\hline & Nunia shak & Portulaca oleracea L. & Portulaceae & - & 28 \\
\hline & Khetpapri & Hedyotis corymbosa (L.) Lamk. & Rubiaceae & 122 & 542 \\
\hline & Bon palong & Mazus rugosus Lour & Scrophulariaceae & - & 172 \\
\hline & Bakopa & Lindernia antipoda $\mathrm{L}$. & Scrophulariaceae & 544 & 1102 \\
\hline & Chuchalo begun & Solanum rostratum Dunal. & Solanaceae & - & 86 \\
\hline & \multicolumn{3}{|c|}{ Total } & 13996 & 54412 \\
\hline
\end{tabular}

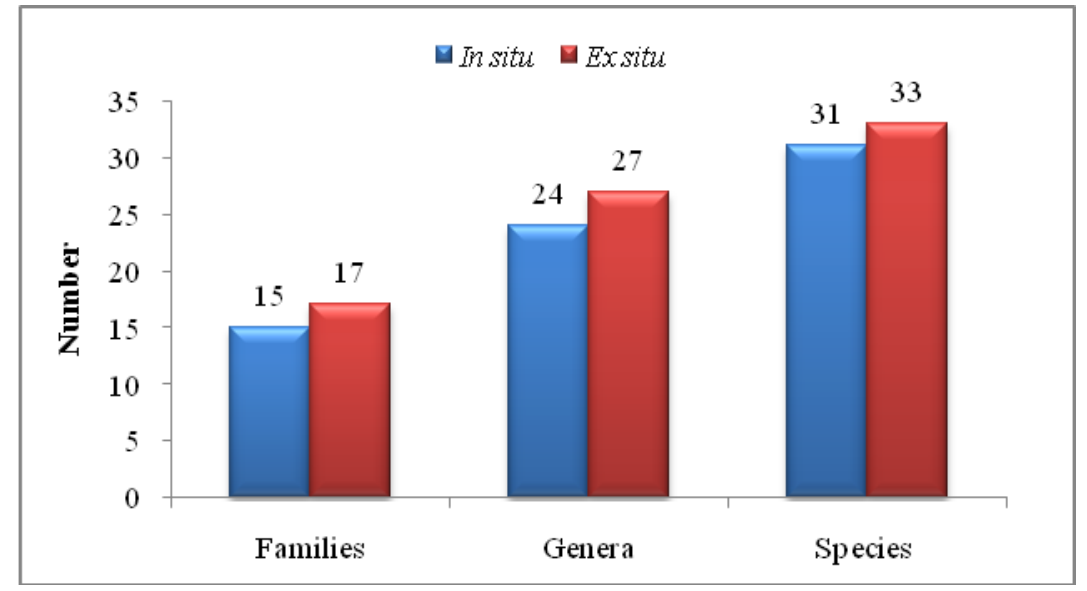

Fig. 5. Number of families, genera and species in the soil weed seedbank under both in situ and ex situ condition 


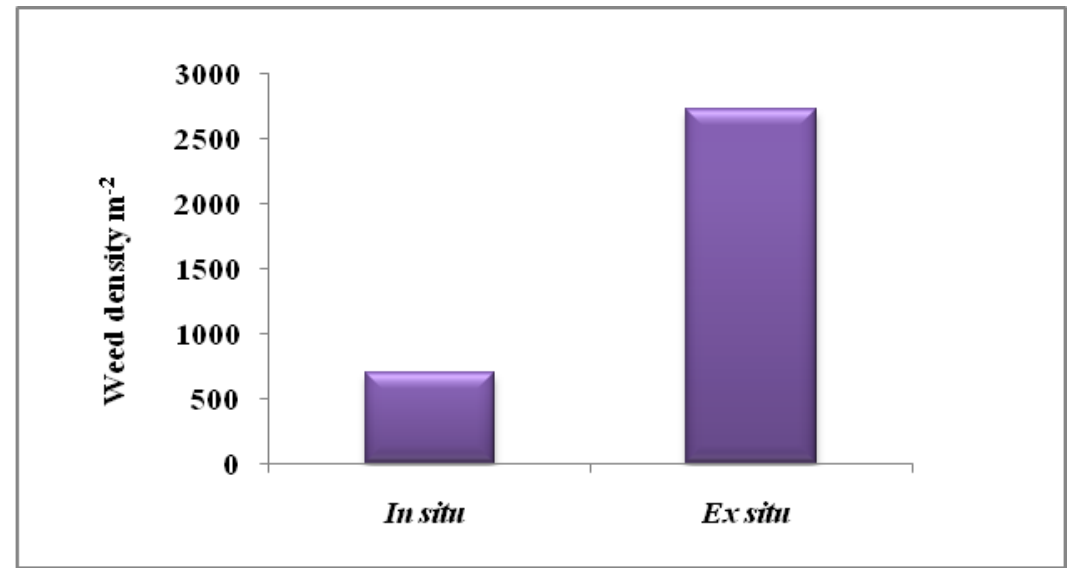

Fig. 6. Comparison of weed density $\mathrm{m}^{-2}$ between in situ and ex situ condition

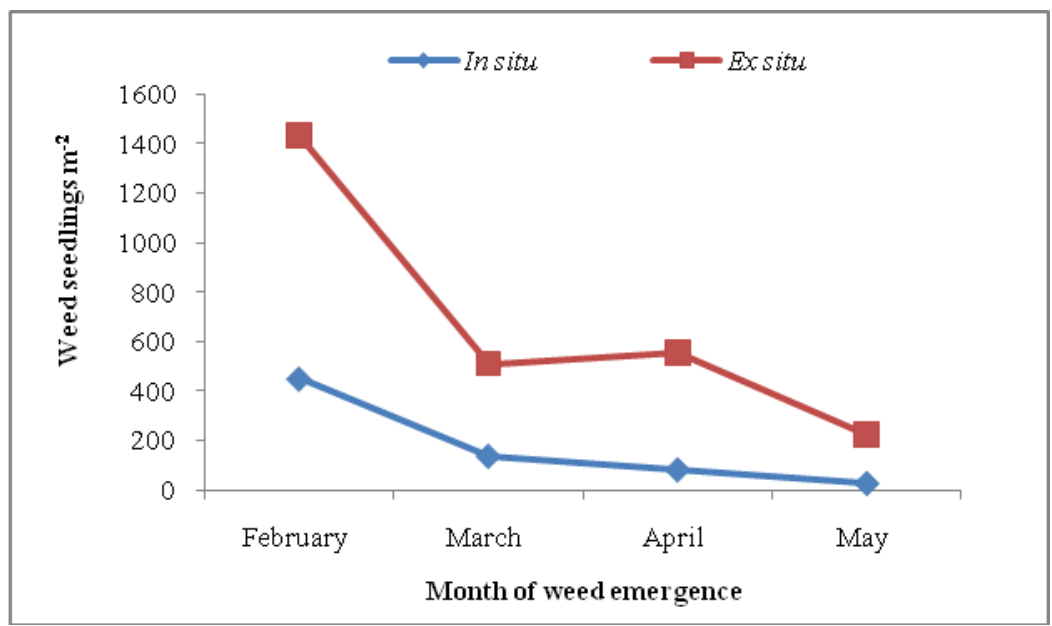

Fig. 7. Emergence pattern of weed seedlings $\left(\mathrm{m}^{-2}\right)$ at different months

\section{Discussion}

The higher floristic diversity was recorded under ex situ condition than under in situ condition. This indicates that the higher number of individuals and species found $e x$ situ contributed to the great floristic diversity in the experimental area. Mesquita et al. (2013) conducted a similar in situ and ex situ study where they observed a total of 13,892 individuals, belonging to 20 families, 40 genera and 60 species in a rice-growing area of Brazil. Among those, 11,530 individuals from 50 species were recorded under ex situ and 2,362 individuals from 34 species were recorded under in situ. The ex situ density was 3,206 plants $\mathrm{m}^{-2}$, which was five times higher than the 653 plants $\mathrm{m}^{-2}$ observed in situ. Floristic diversity was greater under ex situ $\left(H^{\prime}=2.66\right)$ than in situ $\left(H^{\prime}=2.53\right)$.

Species of the family Cyperaceae largely dominated in the soil weed seedbank evaluated both under in situ and ex situ condition. This result agrees with those of similar studies carried out in other tropical regions, such as Kamoshita et al. (2010) observed that $86 \%$ of species present in the seedbanks of 22 rice fields belonged to the Cyperaceae family in Cambodia. In another study in Muda rice granary in north west Peninsular Malaysia,
Begum et al. (2008) found Fimbristylis miliaceae contributing $66.07 \%$ of the total seed reserves to the soil weed seed bank of rice fields.

Differences observed between the amount of seeds germinated in situ and ex situ might be explained by various factors including seed and seedling losses in the field due to the activities of microorganisms, insects, rodents, lizards, birds and other animals. According to Ghersa et al. (2000), weed seed losses due to predators range from $5 \%$ to $15 \%$. Another possible explanation for the differences observed in the present study is that occasional periods of soil water stress and losses (due to intra and inter-specific competition) resulted in germination failure, as observed by Herault and Hiernaux (2004) in a weed seed and population dynamics study carried out in Africa. In the net house, seeds were protected from predators and systematically irrigated, which did not happen in the field. In our ex situ study, the seeds were further protected by the removal of weed seedlings from the trays after the assessments, which eliminated competition, and by the fact that we controlled abiotic factors such as air relative humidity, light and temperature. 
In our present study, the highest percentage of seedling emergence was observed in the first month under both in situ and ex situ condition. The higher germination rates in the first 30 days of our study is probably due to dormancy breaking because of greater exposure to sunlight and temperature variation, as observed by Baskin and Baskin (1998) and Benech-Arnold et al. (2000). Mesquita et al. (2013) stated that, in the greenhouse, approximately $80 \%$ of seeds germinated by day 60. In addition, Begum et al. (2006) observed a germination peak at 30 days in a soil weed seedbank in a rice field in Malaysia. Jensen (1969) also found seedling emergence accounted for only about $25 \%$ of the seeds in the soil and most of those that did so in the first month. $\mathrm{He}$ found the strong correlation between immediate seedling emergence in the net house and field emergence suggests only the first flush of seedling emergence need to be considered. Understanding the causes of differential weed emergence permits more informed decisions, more timely operations, and better management. Without the ability to predict weed emergence, management decisions are less efficient, less reliable, and often more prone to agronomic and financial risk.

\section{Conclusion}

The soil weed seedbank largely determines the species composition and potential densities of weeds that subsequently interfere with crops during the growing season. From the findings, it may be concluded that the floristic diversity of the soil weed seedbank was higher under ex situ than in situ in research fields. Cyperaceae family had the highest species richness under both in situ and ex situ conditions. The density of the soil weed seedbank was approximately five times higher under ex situ than in situ. Our findings could help predict future weed infestation and could lead to improved weed management strategies.

\section{References}

Baskin, C.C. and Baskin, I.M. 1998. Seeds: ecology, biogeography and evolution of dormancy and germination. Academic Press, San Diego. pp 13-17.

Begum, M., Juraimi, A.S., Azmi, M., Rajan, A. and Syed-Omar, S.R 2006. Seedbank and seedling emergence characteristics of weeds in rice field soils of the muda granary area in northwest peninsular Malaysia. The Southeast Asian Journal of Tropical Biology, 13(1): 11-21.

Begum, M., Juraimi, A.S., Azmi, M., Syed-Omar, S.R. and Rajan, A. 2008. Soil seedbank of the Muda rice granary in north west Peninsular Malaysia invaded by the weed Fimbristylis miliaceae (L.) Vahl. Plant Protection Quarterly, 23(4): 157161.

Benech-Arnold, R.L., Sanchez, R.A., Forcela, F., Kruk, B.C. and Ghersa, C.M. 2000. Environmental control of dormancy in weed seed banks in soil. Field Crops Research 60: 105122. https://doi.org/10.1016/S0378-4290(00)00087-3
BBS (Bangladesh Bureau of Statistics) 2016. The Yearbook of Agricultural Statistics of Bangladesh. Statistics Division, Ministry of Planning, Government of the People's Republic of Bangladesh, Dhaka, Bangladesh. pp. 54.

BRRI (Bangladesh Rice Research Institute) 2008. Annual Report for 2007. Bangladesh Rice Research Institute, Gazipur, Bangladesh. pp 16-18.

Cardina, J. and Sparrow, D.H. 1996. A comparison of methods to predict weed seedling populations from the soil seedbank. Weed Science, 44: 46-51.

Chancellor, 1966. The identification of weed seedlings of farm and garden. Blackwell Scientific Publication, Oxford.

Chauhan, B.S. and Johnson, D.E. 2011. Row spacing and weed control timing affect yield of aerobic rice. Field Crop Research, 121: 226-231. https://doi.org/10.1016/j.fcr.2010.12.008

Forcella, F. 1993. Prediction of weed densities from the soil seed reservoir. Integrated Weed Management for Sustainable Agriculture (Hisar, India, 18-20 November 1993). Indian Society of Weed Science, Hisar, India. pp 53-56. PMid:27759235

Ghersa, C.M., Martinez and Ghersa, M.A. 2000. Ecological correlates of weed seed size and persistence in the soil under different tilling systems: implications for weed management. Field Crops Research, 67: 141-148. https://doi.org/10.1016/S0378-4290(00)00089-7

Herault, B. and Hiernaux, P. 2004. Soil seed bank vegetation dynamics in Sahelian fallows; the impact of past cropping and current grazing treatments. Journal of Tropical Ecology, 20: 683691. https://doi.org/10.1017/S0266467404001786

Jensen, H.A. 1969. Content of buried seeds in arable soils in Denmark and its relation to the weed population. Dansk Botanisk Arkiv, 27: 7-57.

Kamoshita, A., Ikeda, H., Yamagishi, J. and Ouk, M. 2010. Ecophysiological study on weed seed bank and weeds in Cambodian paddy fields with contrasting water availability. Weed Biology and Management, 10: 261-272. https://doi.org/10.1111/j.1445-6664.2010.00393.x

Mesquita, M.L.R., Andrade, L.A. and Pereira, W.E. 2013. Floristic diversity of the soil weed seed bank in a rice-growing area of Brazil: in situ and ex situ evaluation. Acta Botanica Brasilica, 27(3): 465-471. https://doi.org/10.1590/S0102-33062013000300001

MoFDM (Ministry of Food and Disaster Management), 2012. Monitoring Report of the National Food Policy Plan of Action and Country Investment Plan, FPMU, Food Division, MoFDM, Khadday Bhaban, Dhaka.

Ndarubu, A. A. and Fadayomi, O. 2006. Relationship between soil, weed seedbank and floristic survey estimation of weed density and species diversity on the sugar cane estate of the Nigeria Sugar Company Ltd, Bacita, Nigeria. Nigerian Journal of Weed Science, 19: 23-31.

Shannon, C.E. and Weaver, W. 1949. The Mathematical Theory of Communication. Urbana, University of Illinois Press.

Singh, A., Kaur, R., Kang, J.S. and Singh, G. 2012. Weed dynamics in rice-wheat cropping system. Global. The Journal of Biological Sciences, 1: 7-16.

Tuesca, D., Nisehsohn, L., Boccanelli, S., Torres, P., and Lewis, J. P. 2004. Weed seedbank and vegetation dynamics in summer crops under two contrasting tillage regimes. Community Ecology, 5: 247-255. https://doi.org/10.1556/ComEc.5.2004.2.12

Webster, T. M., Cardina, J. and White, A. D. 2003. Weed seed rain, soil seedbanks, and seedling recruitment in no-tillage crop rotations. Weed Science, 51: 569-575. https://doi.org/10.1614/0043-1745(2003)051[0569: WSRSSA]2.0.CO;2 